\title{
The use of factor analysis to distinguish the influence of parent material, mining and agriculture on groundwater composition in the Strumica valley, Macedonia
}

\author{
Ivan Boev ${ }^{1}$, Ajka Šorša ${ }^{2}$, Biljana Kovačević ${ }^{3}$, Saša Mitrev ${ }^{3}$ and Blažo Boev ${ }^{1}$ \\ 1 „Goce Delčev“ University Štip, Faculty of Natural and Technical Sciences, Bul. Krste Misirkov, 10-A, P.O. Box 210, 2,000, Štip, Republic of Macedonia \\ (ivan.boev@ugd.edu.mk, blazo.boev@ugd.edu.mk) \\ ${ }^{2}$ Croatian Geological Survey, Department of Geology, Sachsova 2, 10,000, Zagreb, Croatia; (corresponding author: ajka.sorsa@hgi-cgs.hr) \\ 3 "Goce Delčev" University Štip, Faculty of Agricultures, Bul. Krste Misirikov, 10-A, P.O. Box 210, 2,000 Štip, Republic of Macedonia; \\ (biljana.kovacevic@ugd.edu.mk, sasa.mitrev@ugd.edu.mk)
}

doi: $10.4154 / g c .2016 .19$

Article history:

Manuscript received March 01, 2016 Revised manuscript accepted May 31, 2016 Available online June 28, 2016

\begin{abstract}
Determination of groundwater chemistry in the Strumica valley was essential given its widespread use for irrigation in the agricultural industry. 224 samples were collected form boreholes forming the dataset for the study. The groundwater chemical composition was examined for selected analytes: As, $\mathrm{Sr}, \mathrm{Mn}, \mathrm{Ni}, \mathrm{Cu}, \mathrm{Zn}, \mathrm{Mo}, \mathrm{Ba}, \mathrm{Pb}, \mathrm{Na}, \mathrm{Mg}, \mathrm{Al}, \mathrm{K}, \mathrm{Ca}, \mathrm{Ti}, \mathrm{Li}, \mathrm{Cr}, \mathrm{Fe}, \mathrm{U}, \mathrm{CaCO}_{3}, \mathrm{Cl}^{-}$, $\mathrm{NO}_{3}{ }^{-}, \mathrm{NH}_{4}{ }^{+}, \mathrm{SO}_{4}{ }^{2-}$ and $\mathrm{PO}_{4}{ }^{3-}$. The source and internal correlations of the analytes were subjected to multivariate statistical analyses (factor analyses), which yielded 7 factors. Geochemical maps of these factors were generated using the kriging method. The groundwater chemistry was predominantly controlled by the geology with some anthropogenic influence due to agriculture and mining, affecting the concentrations and spatial distribution of arsenic, phosphates, sulphates, nitrates and some metals (copper, iron, chromium, lead, nickel, zinc). Mining of copper/ gold (molybdenum) in the region of llovica increased the concentration of $\mathrm{Al}, \mathrm{Cu}, \mathrm{Pb}, \mathrm{Cr}_{1} \mathrm{NO}_{3}{ }^{-}$, $\mathrm{Ni}, \mathrm{Zn}, \mathrm{Na}, \mathrm{K}, \mathrm{Li}$ and $\mathrm{PO}_{4}{ }^{3-}$ in groundwater, but only at a local level.
\end{abstract}

Keywords: groundwater, chemistry, factor analyses, Strumica, Macedonia

\section{STUDY AREA}

The Republic of Macedonia is located in southern Europe, in the central part of the Balkans, at latitude of approximately $42^{\circ}$ north and longitude of $22^{\circ}$ east (Fig. 1), and covers a geographic area

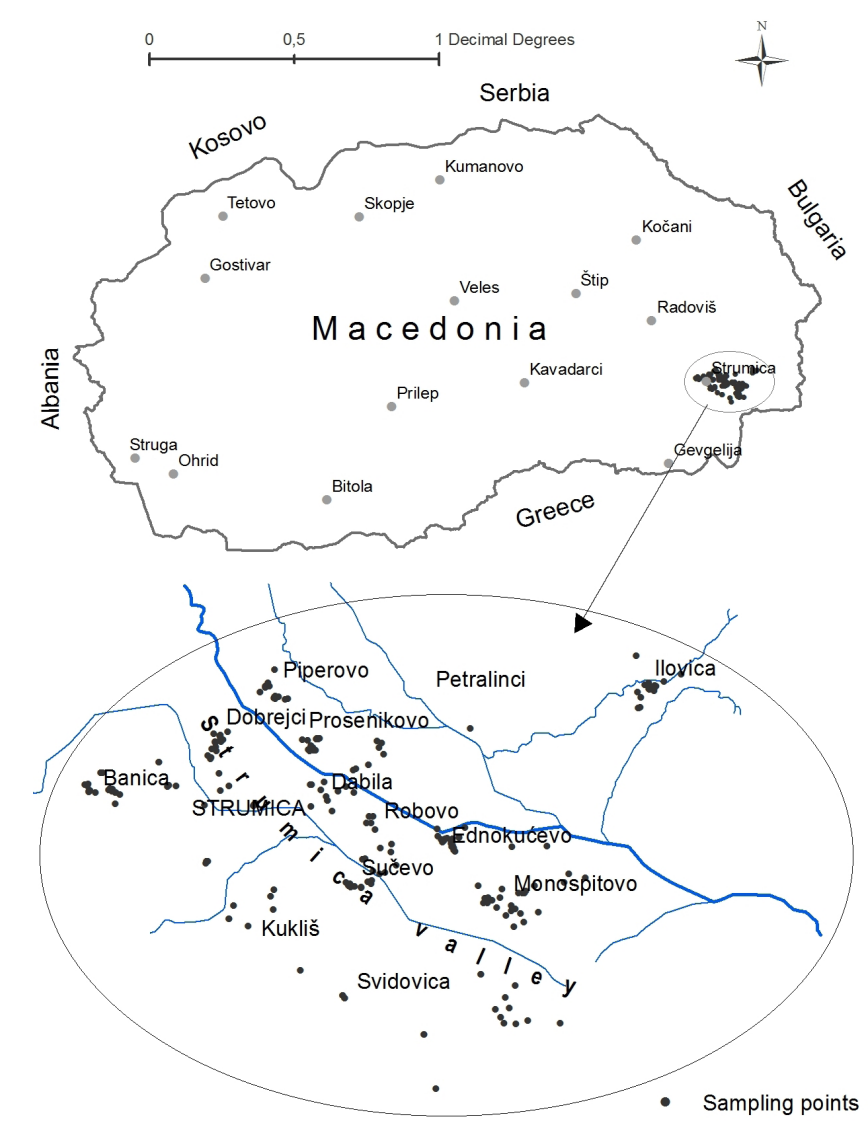

Figure 1. Study area.$$
\text { and longitude of } 22^{\circ} \text { east (Fig. 1), and covers a geographic area }
$$

\section{INTRODUCTION}

Influences on the chemistry of groundwater are numerous. Apart from the geological setting and hydrogeological characteristics, groundwater quality can be impacted by anthropogenic influences. Increased population growth rates, intensive agriculture and mining could significantly change the groundwater geochemistry. The groundwater investigation in Macedonia as part of the project „Hydrogeological survey of Groundwater in Macedonia” was one of the newest projects in this area of research (JOVANOVSKI, 2009). In addition, numerous studies were also performed in Macedonia and the Strumica valley, including a systematic hydrogeological investigation in Macedonia, performed as part of the framework of the hydrogeological map of SFR Yugoslavia, 1:500 000 (IVKOVIĆ et al., 1983). MICEVSKI et al. (2005) studied the hydro geothermal potential of the Strumica valley. A water quality assessment was undertaken of the water resources in the Strumica river basin (POPOVSKA \& GESHOVSKA, 2014), and the chemical element composition of water samples from the river Vardar (Republic of Macedonia and Greece) and its major tributaries was also studied (ILIĆ POPOV et al., 2014). Some hydrochemical data were determined in the groundwaters of the Pelagonia valley (MIRČOVSKI et al., 2015). More recently, the concentration of macro-, micro-, trace and ultratrace elements in some natural waters from eastern and south-eastern Macedonia were reviewed by ŠIJAKOVA-IVANOVA \& AMBARKOVA (2015).

Groundwater in the Strumica valley was used mainly in the irrigation system and to a considerably lesser degree as drinking water. The main goal of this investigation was to establish any correlations between various analytes, define their sources (geogenic and anthropogenic), present their spatial distribution and investigate the influence of the Ilovica mining area on groundwater composition in the region using multivariate statistics (factor analyses). 
of $25,713 \mathrm{~km}^{2}$, of which $79 \%$ is composed of hills/mountainous areas, $19.1 \%$ plains and $1.9 \%$ surface water.

The Strumica valley is located in the south east of Macedonia, near the border with Bulgaria. The biggest city is Strumica, with 45,000 inhabitants. The Strumica river flows through the valley and the drainage basin gravitates to the Black Sea. Macedonia's climate is variable with different climatic zones, from continental to Mediterranean being represented. The Strumica valley has a temperate Mediterranean climate, characterized by warm and dry summers and cold wet winters. The temperature varies between $40^{\circ} \mathrm{C}$ in summer to $-20^{\circ} \mathrm{C}$ in winter (CARTER, 2007). The annual average rainfall is approximately 547 millimetres (JOVANOVSKI, 2009), and prevailing winds are from the north-west and south-east.

\section{GEOLOGICAL, HYDROGEOLOGICAL AND PEDOLOGICAL CHARACTERISTICS}

The largest part of the investigated area is located in the Strumica valley. The valley is a tectonic graben formed in the Pliocene between two parallel faults, one to the north along the border of the Ogražden mountain in the Serbo-Macedonian massif and the other to the south, along the border of Belasica mountain in the Vardar zone (RAKIKEVIK et al., 1978, 1980; MICEVSKI et al., 2005; Fig. 2). The oldest rocks are Precambrian high-temperature metamorphites, represented by various gneisses and schists. Metamorphites and magmatites prevailed in the older Palaeozoic. The younger Palaeozoic rocks were not found. The Mesozoic (Jurassic) is represented by diabase, granite, granodiorite and rhyolites. The Tertiary rocks are comprised of Upper Eocene volcanogenic sediments, conglomerates and sandstones, dacites and andesites and the Pliocene epoch is represented by clays, sands and gravels. The Strumica valley is predominantly covered by Quaternary sediments: sandy clay, gravel, sands and tufaceous sediments. MICEVSKI et al. (2005), on the basis of geophysical data, supposed that the depth of the basin varies from $700-1,200 \mathrm{~m}$.

The metal occurrences are numerous throughout the investigated area: around Strumica, Kukliš, Veljuša; the northern Strumica drainage basin in Kalugerica and Poderiš, but most importantly in Ilovica located to the east of the investigated area (RAKIKEVIK et al., 1978, 1980; POPOVSKA \& GESHOVSKA, 2014). The copper/gold (molybdenum) mine in Ilovica extends over 3,100 hectares (CARTER, 2007).
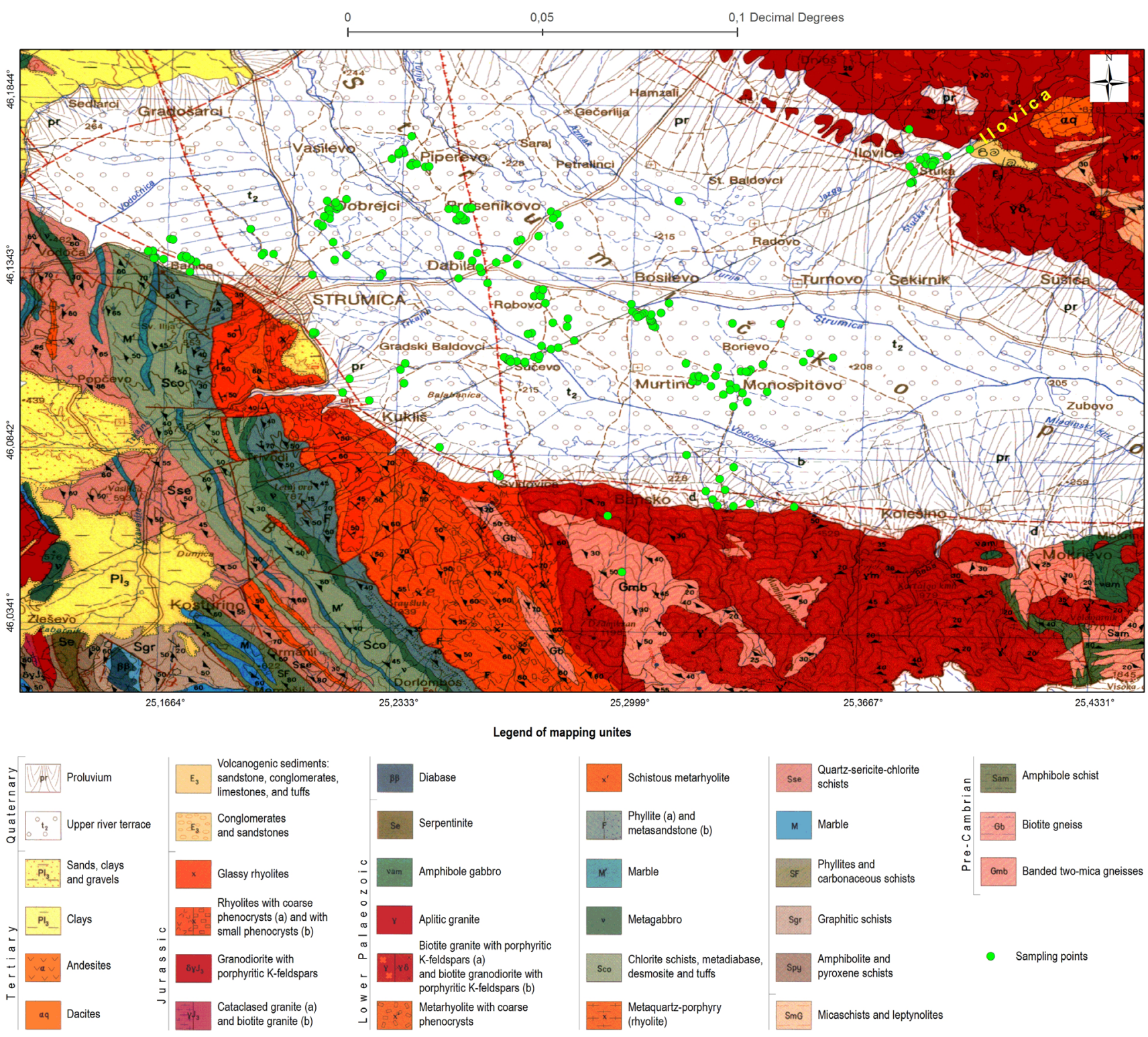

Figure 2. A geological map of the investigated area (RAKIKEVIK et al., 1978, 1980; MICEVSKI et al., 2005.) 
Macedonia is divided into four catchments: the Vardar, Strumica, Crni Drim and Južna Morava basins. The catchment area of the Strumica river comprises part of the Serbo-Macedonian massif to the north-east, the Strumica valley in the middle and part of the Vardar zone to the south-west (POPOVSKA, 2014, figs. 2, 3). The importance of groundwater in this area and its use has a long history. According to IVKOVIĆ et al. (1983), a special effort was made in the Strumica valley of building hydro melioration systems which involved digging a number of wells to depths between 15 to $250 \mathrm{~m}$. Groundwater monitoring in the Strumica catchment basin was established in 1953 with 23 piezometric wells, but since 2000 only two of them have been in use. Water quality is regulated by the „Law on waters” (Official Gazette of RM 4/98, 1998), and the surface waters (rivers, natural and manmade lakes) were classified into five classes (Official Gazette of RM 18/99, 1999). Water quality in the Strumica basin belongs to classes III and IV, i.e. water for irrigation and polluted water, respectively. An assessment based on the geochemistry of some natural waters in Macedonia including five samples from the Strumica valley showed satisfactory levels of water quality (ŠIJAKOVA-IVANOVA \& AMBARKOVA, 2015).

Fluvisols cover the flood plain surface of the Strumica river. These alluvial soils were developed on the Proluvium and Upper River terrace sediments (MAKSOIL, 2016; Fig. 2.). The sampling points were predominantly located at the Fluvisol, about $10 \%$ were in urban areas, only 6 samples north-west from Strumica city at Humic Calcaric Regosol, 2 samples south from Bansko city at Cambisol and 2 samples north-east from Ilovica settlement at Leptosol and Regosol.

Land use was observed at Corine Land Cover 2006 (DISCOMAP, 2016). The largest part of the investigation was undertaken on non-irrigated arable land and complex cultivation patterns land use categories. Land use of the discontinuous urban fabric, inland marshes, natural grasslands and vineyards covered a smaller part of the area. The sample points are distributed over all land use categories, except for the $n a$ tural grasslands.

\section{MATERIALS AND METHODS}

\subsection{Sampling and analysis}

Groundwater samples were collected from 224 boreholes over the field area. Water from the borehole was pumped out for $10 \mathrm{minu}-$ tes by electrical pump. Samples were stored in 11 sterile glass bottles which were washed out several times with water from the borehole before filling to the top in order to exclude air. Samples were transferred to the Laboratory for Plant and Environmental Protection at the Agriculture faculty, UGD-Štip, within two hours. Unfiltered and untreated samples were used to determine alkalinity within an hour after arrival at the laboratory. The rest of each sample was filtered (MN $640 \mathrm{~m}$ de Ø125, No. 43 (white

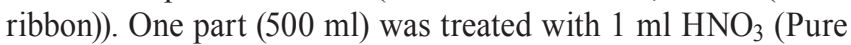
trace, Sigma) for qualitative and quantitative determination of sulphates and trace elements, $300 \mathrm{ml}$ was treated with $0.6 \mathrm{ml}$ $\mathrm{H}_{2} \mathrm{SO}_{4}$ (Pure trace, Sigma) for determination of nitrates and ammonia. Samples were stored in a refrigerator at $+4{ }^{\circ} \mathrm{C}$ and tested within two days (JOHNSTON, 2007).

Alkalinity is determined according to the EPA Method 305.1 (1974a) and expressed as $\mathrm{mg} / \mathrm{l} \mathrm{CaCO}_{3}$. For that purpose, $20 \mathrm{ml}$ of the sample, $30 \mathrm{ml}$ distilled water and several drops of methyl orange are transferred to a $250 \mathrm{ml}$ Erlenmeyer flask for titration with $0.01 \mathrm{M} \mathrm{HCl}$ until the colour of white wine (pale yellow).
Sulphates were determined by the colorimetric method using a spectrophotometer (JENWAY 6715, UV Vis) according to the EPA method 375.4 (1978). For this purpose, $20 \mathrm{ml}$ concentrated sample was transferred to a $25 \mathrm{ml}$ volumetric flask. Then, $1 \mathrm{ml}$ glycol alcohol, $1 \mathrm{ml} \mathrm{NaCl}(60 \mathrm{~g} / \mathrm{L}+1.25 \mathrm{ml} \mathrm{HCl}), 1 \mathrm{ml} \mathrm{BaCl} 2$ $(150 \mathrm{~g} / \mathrm{l})$ and distilled water was added up to the mark. Absorbance was read after 30 minutes at a wavelength of $420 \mathrm{~nm}$. The apparatus was calibrated in five calibration levels in the concentration range of $0.1-0.5 \mathrm{mg} / \mathrm{l}$ using a sulphates standard for IC (1000 mg/l $\pm 4 \mathrm{mg} / \mathrm{l}$, Fluka analytical).

Determination of nitrates was undertaken by the colorimetric method using the same spectrophotometer type JENWAY 6715 , UV Vis. The concentrated sample was directly transferred into a $2 \mathrm{ml}$ cuvette and the absorbance was read at wavelengths of $220 \mathrm{~nm}$ and $275 \mathrm{~nm}$. The apparatus was calibrated in five calibration levels in a range from $1-5 \mathrm{mg} / \mathrm{l}$ using the Nitrate standard for IC, $1000 \mathrm{mg} / \mathrm{l} \pm 4 \mathrm{mg} / \mathrm{l}$ (Fluka analytical) (DALMACIJA \& AGBABA, 2006).

The $\mathrm{PO}_{4}{ }^{3-}$ was stochiometrically determined from the value of $\mathrm{P}$ dissolved in the waters with the assumption that all the $\mathrm{P}$ is in phosphate forms. P was determined by inductively coupled plasma mass spectrometry (ICP - MS), apparatus type Agilend $7500 \mathrm{CX}$. Calibration of the apparatus for $\mathrm{P}$ is in range from 10 $-100 \mu \mathrm{g} / \mathrm{l}$. Results are expressed as $\mu \mathrm{g} / 1 \mathrm{PO}_{4}{ }^{3-}$.

Ammonium ions were determined by the colorimetric method using the spectrophotometer type JENWAY 6715, UV Vis. Here, $20 \mathrm{ml}$ of the treated sample was transferred to a $25 \mathrm{ml}$ volumetric flask. Then $1 \mathrm{ml}$ of Potassium sodium tartrate (25\%), $1 \mathrm{ml} \mathrm{NaOH}$ (7.5\%), $1 \mathrm{ml}$ Nessler's reagent and distilled water were add up to the mark. The absorbance was read after 30 minutes at a wavelength of $420 \mathrm{~nm}$. The apparatus was calibrated in five calibration levels in the concentration range of $5-30 \mathrm{mg} / \mathrm{l}$ using the ammonium standard for IC $(1000 \mathrm{mg} / 1 \pm 4 \mathrm{mg} / \mathrm{l}$, Fluka analytical) (EPA, 1974b).

Qualitative and quantitative determination of trace elements was made by inductively coupled plasma mass spectrometry (ICP - MS), using an Agilend 7500 CX apparatus. Calibration of the apparatus for the total cation and anion content of the elements $\mathrm{Li}, \mathrm{Ti}, \mathrm{Cr}, \mathrm{Mn}, \mathrm{Ni}, \mathrm{Cu}$, As and $\mathrm{Pb}$ was in the concentration range from $1-10 \mu \mathrm{g} / \mathrm{l}$. For $\mathrm{Sr}$ (tot) and $\mathrm{Ba}$ (tot) the calibration range was from $10-100 \mu \mathrm{g} / \mathrm{l}$ and for $\mathrm{Ca}$ (tot), $\mathrm{Mg}$ (tot), $\mathrm{Na}$ and $\mathrm{K}$ a calibration range from $1,000-5,000 \mu \mathrm{g} / \mathrm{l}$ was used. Multi element standard solutions (Periodic table mix 1 for ICP, 92091, Fluka) were used for calibration of these elements. For calibration of the total oxidation state of Mo an Agilent standard solution 7500 series PA Tuning 2 (100 mg/l) (CAS: 7697-37-2) was used in the range of $1-10 \mu \mathrm{g} / \mathrm{l}$. U was calibrated in the range of $1-10 \mu \mathrm{g} / \mathrm{l}$ using an Agilent standard solution 7500 Series PA Tuning 1 (5 $\mathrm{mg} / \mathrm{l})$ (7697-37-2). The Titanium standard for ICP (998 mg/l \pm 2 $\mathrm{mg} / \mathrm{l}$ ) was used for calibration of $\mathrm{Ti}$ (tot) in the calibration range of $1-10 \mu \mathrm{g} / \mathrm{l}$. A chloride standard for ICP $(1,000 \mathrm{mg} / \mathrm{l})$ was used for calibration of $\mathrm{Cl}$ (tot) in the range of $1,000-5,000 \mu \mathrm{g} / \mathrm{l}$. The bias ranged from $1 \%-10 \%$ and precision, expressed as intermediate precision was better than $10 \%$ for all the analysed elements.

\subsection{Data processing}

The analytical data were screened in order to carry out univariate and multivariate (factor analysis) statistical analyses. Analytical results falling below the detection limit (DL; ROLLINSON, 1993) were calculated to half of the DL value for the particular element. The geochemical data generally never follow a normal distribution, but for carrying out factor analyses it is essential that 
Table 1. Descriptive statistics of the contents of analyses in the groundwater samples $(n=224)$.

\begin{tabular}{|c|c|c|c|c|c|c|}
\hline Element/lon & Mean & Median & Standard Deviation & Range & Minimum & Maximum \\
\hline As (mg/l) & 20.68 & 1.91 & 38.41 & 209.51 & 0.08 & 209.59 \\
\hline $\mathrm{Sr}(\mathrm{mg} / \mathrm{l})$ & 252.53 & 188.32 & 206.78 & 1244.18 & 0.09 & 1244.27 \\
\hline $\mathrm{Mn}(\mathrm{mg} / \mathrm{l})$ & 443.32 & 166.28 & 625.84 & 3600.25 & 0.01 & 3600.27 \\
\hline $\mathrm{Ni}(\mathrm{mg} / \mathrm{l})$ & 3.38 & 2.62 & 2.67 & 21.28 & 0.31 & 21.58 \\
\hline $\mathrm{Cu}(\mathrm{mg} / \mathrm{l})$ & 1.38 & 1.05 & 1.70 & 21.45 & 0.10 & 21.55 \\
\hline $\mathrm{Zn}(\mathrm{mg} / \mathrm{l})$ & 48.88 & 13.95 & 155.35 & 1369.10 & 2.31 & 1371.41 \\
\hline Mo (mg/l) & 17.61 & 8.52 & 25.38 & 165.65 & 0.52 & 166.17 \\
\hline $\mathrm{Ba}(\mathrm{mg} / \mathrm{l})$ & 28.04 & 22.60 & 21.01 & 127.42 & 0.55 & 127.97 \\
\hline $\mathrm{Pb}(\mathrm{mg} / \mathrm{l})$ & 0.89 & 0.49 & 1.55 & 16.28 & 0.06 & 16.35 \\
\hline $\mathrm{Na}(\mathrm{mg} / \mathrm{l})$ & 7.18 & 6.10 & 4.94 & 36.38 & 0.33 & 36.71 \\
\hline $\mathrm{Mg}(\mathrm{mg} / \mathrm{l})$ & 12.62 & 9.07 & 12.44 & 95.83 & 0.31 & 96.14 \\
\hline $\mathrm{Al}(\mathrm{mg} / \mathrm{l})$ & 9.96 & 5.32 & 21.62 & 208.96 & 0.46 & 209.43 \\
\hline $\mathrm{K}(\mathrm{mg} / \mathrm{l})$ & 11.63 & 5.48 & 33.74 & 353.76 & 0.68 & 354.44 \\
\hline $\mathrm{Ti}(\mathrm{mg} / \mathrm{l})$ & 154.76 & 123.16 & 136.27 & 1034.49 & 1.98 & 1036.47 \\
\hline $\mathrm{Li}(\mathrm{mg} / \mathrm{l})$ & 6.05 & 2.62 & 9.74 & 86.00 & 0.40 & 86.40 \\
\hline $\mathrm{Cr}(\mathrm{mg} / \mathrm{l})$ & 0.79 & 0.48 & 0.92 & 6.04 & 0.00 & 6.04 \\
\hline $\mathrm{Fe}(\mathrm{mg} / \mathrm{l})$ & 197.19 & 70.35 & 364.61 & 3160.71 & 5.00 & 3165.71 \\
\hline $\mathrm{U}(\mathrm{mg} / \mathrm{l})$ & 2.99 & 0.67 & 8.91 & 95.34 & 0.14 & 95.49 \\
\hline $\mathrm{CaCO}_{3}(\mathrm{mg} / \mathrm{l})$ & 213.56 & 193.62 & 138.91 & 915.04 & 0.03 & 915.07 \\
\hline $\mathrm{Cl}^{-}(\mathrm{mg} / \mathrm{l})$ & 36.54 & 22.18 & 52.23 & 610.11 & 4.19 & 614.30 \\
\hline $\mathrm{NO}_{3}^{-}(\mathrm{mg} / \mathrm{l})$ & 21.85 & 2.86 & 44.01 & 284.30 & 0.14 & 284.44 \\
\hline $\mathrm{NH}_{4}^{+}(\mathrm{mg} / \mathrm{l})$ & 0.96 & 0.07 & 4.63 & 55.86 & 0.03 & 55.89 \\
\hline $\mathrm{SO}_{4}{ }^{2-}(\mathrm{mg} / \mathrm{l})$ & 23.73 & 15.86 & 35.66 & 300.25 & 0.25 & 300.50 \\
\hline $\mathrm{PO}_{4}^{3-}(\mathrm{mg} / \mathrm{l})$ & 0.51 & 0.16 & 1.05 & 7.80 & 0.00 & 7.80 \\
\hline
\end{tabular}

all variables are close to it (REIMANN \& FILZMOSER, 2000). Therefore, the data were log-transformed to base 10 logarithms (REIMANN et al., 2008). Factor analysis (FA) of the data was performed to reduce the observed variables and detect possible hidden correlations in the dataset in order to acquire a better understanding and to simplify the interpretation. The Kaiser-MeyerOlkin test (KMO) and Bartlett's test of Sphericity were used to estimate data adequacy for factorizing. The eigenvalues greater than 1 were selected (KAISER, 1960). The retained factor loadings were rotated by Varimax rotation with Kaiser Normalization to facilitate explanation of the factors. Statistical analysis was performed using IBM SPSS software.

The calculated factor scores were stored as a new variable in the database and used for generating geochemical maps in GIS software ArcGIS ${ }^{\mathrm{TM}}$ using its Geostatistical Analyst extension. After variogram analyses, the geochemical maps based on the factor score values were generated using the kriging method. The factor scores on the factor maps were classified into 50 classes (one class for two percentiles) to gain a smooth transition from the lowest to the highest values. As a result, the different geogenic and/or anthropogenic influences of the factorized geochemical data could be evaluated.

\section{RESULTS AND DISCUSSION}

Table 1. reveals that the range for most analytes proved to be considerable. Comparing the mean and median values, it can be seen that the means were notable higher. The descriptive statistics of the data conclusively indicated the great variability of the concentration of a particular analyte in the groundwater.

The values of the KMO test of 0.722 and Bartlett's test of sphericity $<0.001$ showed that the data were adequate for factorization. The 7 factors were retained (those with eigenvalues $>1$ ) which explains $70.0 \%$ of the variance. A more detailed over- view about the factors is given in Tables 2. and 3. The influence of a particular analyte to the factor increases by the increasing the value of its factor loading. The biggest impacts have factor loadings greater than 0.5 , since lower factor loadings give only some additional explanation about an individual factor. In that sense the factor loadings lower than 0.3 could be ignored.

Table 2. The eigenvalue and explained variance of retained factors.

\begin{tabular}{lccc}
\hline Factor & Eigenvalue & Variance (\%) & Cumulative variance (\%) \\
\hline 1 & 3.47 & 13.9 & 13.9 \\
2 & 3.42 & 13.7 & 27.6 \\
3 & 2.79 & 11.2 & 38.8 \\
4 & 2.39 & 9.6 & 48.3 \\
5 & 1.99 & 8.0 & 56.3 \\
6 & 1.87 & 7.5 & 63.7 \\
7 & 1.56 & 6.2 & 70.0 \\
\hline
\end{tabular}

The association of analytes within the factor loadings greater than 0.5 for factor 1 were As (0.80), $\mathrm{Fe}(0.74), \mathrm{Mn}(0.68), \mathrm{SO}_{4}{ }^{2-}$ $(-0.61), \mathrm{Ba}(0.58)$ and $\mathrm{PO}_{4}{ }^{3-}(0.54)$. The factor scores were highest in the lower part of the Strumica river and at the mouth of the Turija and Štučka tributaries at Robovo, Sučevo, Bosilovo, Ednokućevo, Murtino, Radovo, Turnovo, Borievo and Monospitovo (Tab. 3; Figs. 2 \& 3). An elevated concentration of arsenic in groundwater was due to weathering and leaching As from the As-rich minerals of magmatic and metamorphic rocks originating from the Serbo-Macedonian massif and the Vardar zone. The arsenic could partly be transported from the northern part of the Strumica river from the rich metal occurrences around areas such as the village of Podareš. The permeability of Fluvisol and alluvial parent material and use of pesticides, fertilizers, sludge and 
Table 3. Rotated factor matrix of the factors.

\begin{tabular}{|c|c|c|c|c|c|c|c|}
\hline \multirow{2}{*}{ Analyte } & \multicolumn{7}{|c|}{ Factor loading } \\
\hline & 1 & 2 & 3 & 4 & 5 & 6 & 7 \\
\hline As & 0.80 & -0.01 & -0.26 & 0.24 & -0.04 & 0.09 & 0.09 \\
\hline $\mathrm{Fe}$ & 0.74 & -0.05 & 0.20 & -0.05 & 0.02 & -0.09 & -0.07 \\
\hline $\mathrm{Mn}$ & 0.68 & 0.11 & -0.11 & 0.43 & -0.29 & 0.06 & -0.14 \\
\hline $\mathrm{SO}_{4}{ }^{2-}$ & -0.61 & 0.45 & 0.26 & -0.10 & 0.06 & 0.07 & 0.15 \\
\hline $\mathrm{Ba}$ & 0.58 & 0.54 & 0.05 & 0.11 & 0.32 & -0.02 & 0.02 \\
\hline $\mathrm{NH}_{4}^{+}$ & 0.48 & 0.02 & -0.35 & 0.10 & -0.20 & -0.36 & 0.12 \\
\hline $\mathrm{Mg}$ & -0.14 & 0.80 & 0.06 & 0.05 & 0.20 & -0.16 & -0.07 \\
\hline $\mathrm{Ca}$ & 0.06 & 0.75 & 0.10 & 0.19 & 0.35 & 0.26 & -0.00 \\
\hline $\mathrm{Ti}$ & 0.20 & 0.69 & -0.08 & -0.13 & -0.28 & -0.20 & 0.19 \\
\hline $\mathrm{Cl}^{-}$ & -0.41 & 0.69 & 0.30 & 0.23 & 0.14 & 0.18 & 0.01 \\
\hline Mo & 0.12 & 0.62 & -0.14 & 0.21 & -0.42 & 0.03 & 0.09 \\
\hline$U$ & -0.40 & 0.46 & 0.24 & -0.26 & 0.11 & 0.04 & 0.41 \\
\hline $\mathrm{Al}$ & 0.00 & -0.14 & 0.79 & -0.15 & 0.06 & -0.04 & 0.20 \\
\hline $\mathrm{Cu}$ & -0.16 & 0.05 & 0.78 & 0.04 & 0.13 & 0.14 & -0.21 \\
\hline $\mathrm{Pb}$ & 0.00 & 0.06 & 0.67 & -0.15 & 0.03 & -0.19 & 0.28 \\
\hline $\mathrm{Cr}$ & -0.09 & 0.20 & 0.51 & 0.02 & 0.15 & -0.06 & -0.05 \\
\hline $\mathrm{CaCO}_{3}$ & 0.17 & 0.01 & -0.11 & 0.94 & -0.08 & -0.04 & 0.02 \\
\hline $\mathrm{Sr}$ & 0.12 & 0.2 & -0.04 & 0.93 & 0.11 & 0.00 & 0.11 \\
\hline $\mathrm{NO}_{3}^{-}$ & -0.21 & 0.17 & 0.21 & -0.07 & 0.73 & 0.27 & 0.22 \\
\hline $\mathrm{Ni}$ & 0.06 & 0.09 & 0.49 & 0.06 & 0.56 & 0.13 & 0.20 \\
\hline $\mathrm{Zn}$ & 0.08 & 0.07 & 0.11 & 0.21 & 0.54 & -0.47 & 0.04 \\
\hline $\mathrm{Na}$ & 0.14 & -0.07 & -0.17 & -0.01 & -0.07 & 0.76 & -0.05 \\
\hline $\mathrm{K}$ & -0.16 & 0.09 & 0.10 & 0.05 & 0.26 & 0.74 & 0.11 \\
\hline $\mathrm{Li}$ & -0.14 & 0.06 & 0.13 & 0.20 & 0.19 & -0.06 & 0.81 \\
\hline $\mathrm{PO}_{4}^{3-}$ & 0.54 & 0.05 & -0.04 & -0.07 & 0.05 & 0.21 & 0.57 \\
\hline
\end{tabular}

manure in the intensive agricultural production increased the concentration of arsenic in both soil and groundwater (MAKSOIL, 2016; DISCOMAP, 2016).

According to KABATA-PENDIAS \& PENDIAS (2001), in well drained soils and sediments, arsenic leaches out downwards into the lower soil horizons. Additionally, irrigation with arsenic loaded groundwater recycles As again to the groundwater. These assumptions suggest that part of the arsenic content is of anthropogenic origin.

The geochemical behaviour of other analytes in this factor was close. The colloidal $\mathrm{Fe}$ and $\mathrm{Mn}$ oxides are important in the sorption other colloidal substances and ions, such as $\mathrm{PO}_{4}{ }^{3-}$ ion (KABATA-PENDIAS \& MUKHERJEE, 2007; KABATA-PENDIAS \& PENDIAS, 2001). Ba is associated with $\mathrm{K}$ in the magmatic rocks, mobilizes during weathering and is easily adsorbed onto $\mathrm{Mn}$ and $\mathrm{Fe}$ oxides. The Barium ion is mobile in solutions without sulphates as revealed by the negative factor loadings of $\mathrm{SO}_{4}{ }^{2-}$.

There were also relatively high negative factor loadings of two more analytes $\mathrm{Cl}^{-}$and $\mathrm{U}$. The lack of these elements indicate that in the geological background there are small amounts of $\mathrm{Na}$, $\mathrm{Ca}$ or $\mathrm{Mg}$ chlorides or soluble uranium minerals present.

The lowest factor scores were recorded in the areas of Bansko and Banica. The low values were also on the upper flow part of the Strumica river, north of the confluence of the Jazga and Turija rivers and in the Ilovica area.

The spatial distribution of factor scores of factor 2 is divided by separation lines running north north-east - south south-west which passed through Murtino (Fig. 4). Towards Strumica city were located the highest factor scores values while the smallest values were at the opposite part of the investigated area. This was clearly connected with the geology (RAKIKEVIK et al., 1978, 1980). The magmatite and metamorphites of the Vardar zone near Strumica city and beyond in the Strumica valley, are composed of rocks which when weathered release to the environment and groundwater, ions with the highest factor loadings, including; $\mathrm{Mg}$ (0.80), Ca (0.75), Ti (0.69), $\mathrm{Cl}^{-}(0.69)$, Mo (0.62), Ba (0.54), U $(0.46)$ and $\mathrm{SO}_{4}{ }^{2-}(0.45)$ (Tab. 3; Fig. 4). A large proportion of the analytes have their geological origin in the rocks of the Vardar zone and the Quaternary proluvium of the upper river terrace, (mainly connected to that zone and partly to the Serbo- Macedonian massif), (Fig. 2). Several metal occurrences were recorded

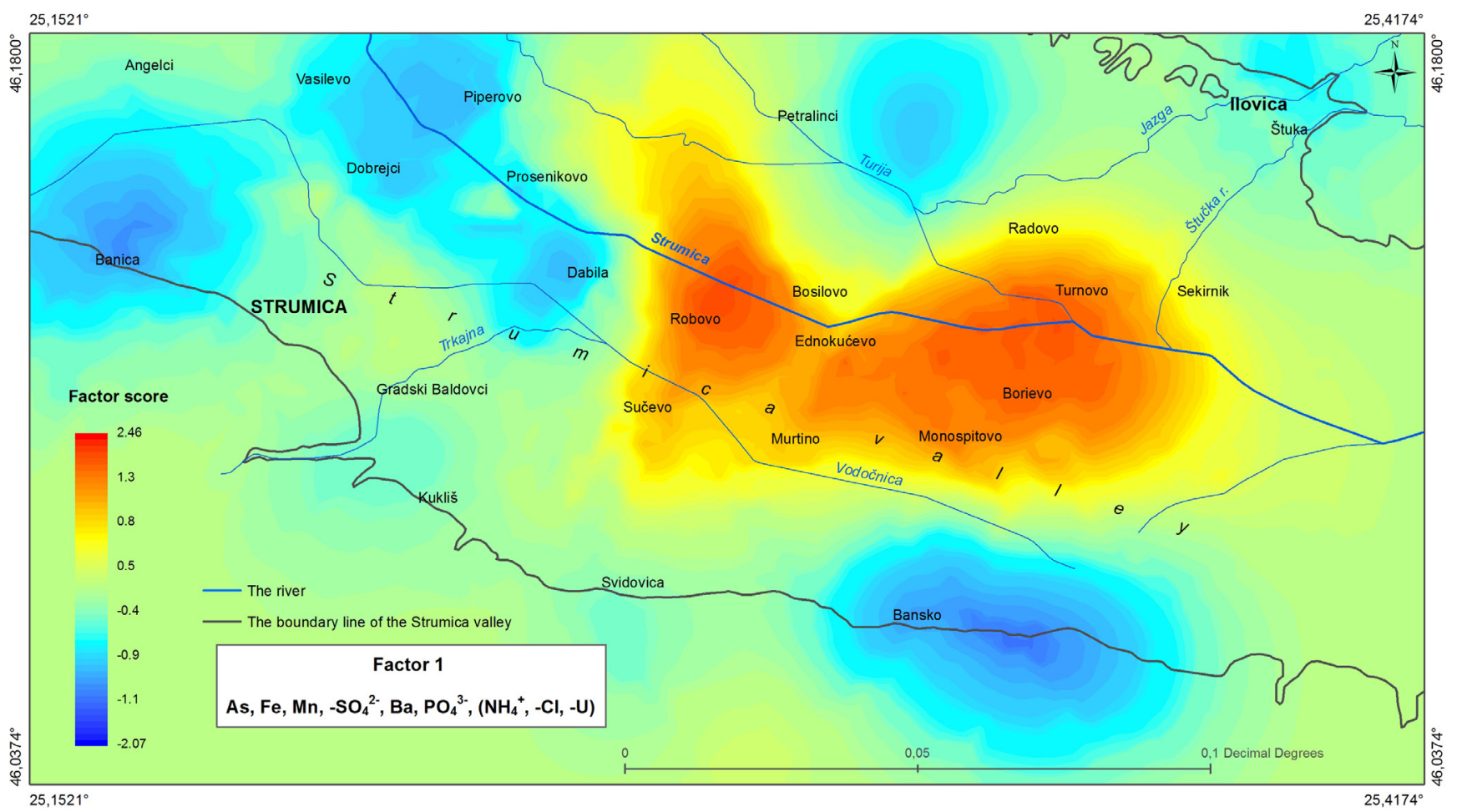

Figure 3. Spatial distribution of factor scores of Factor 1. 


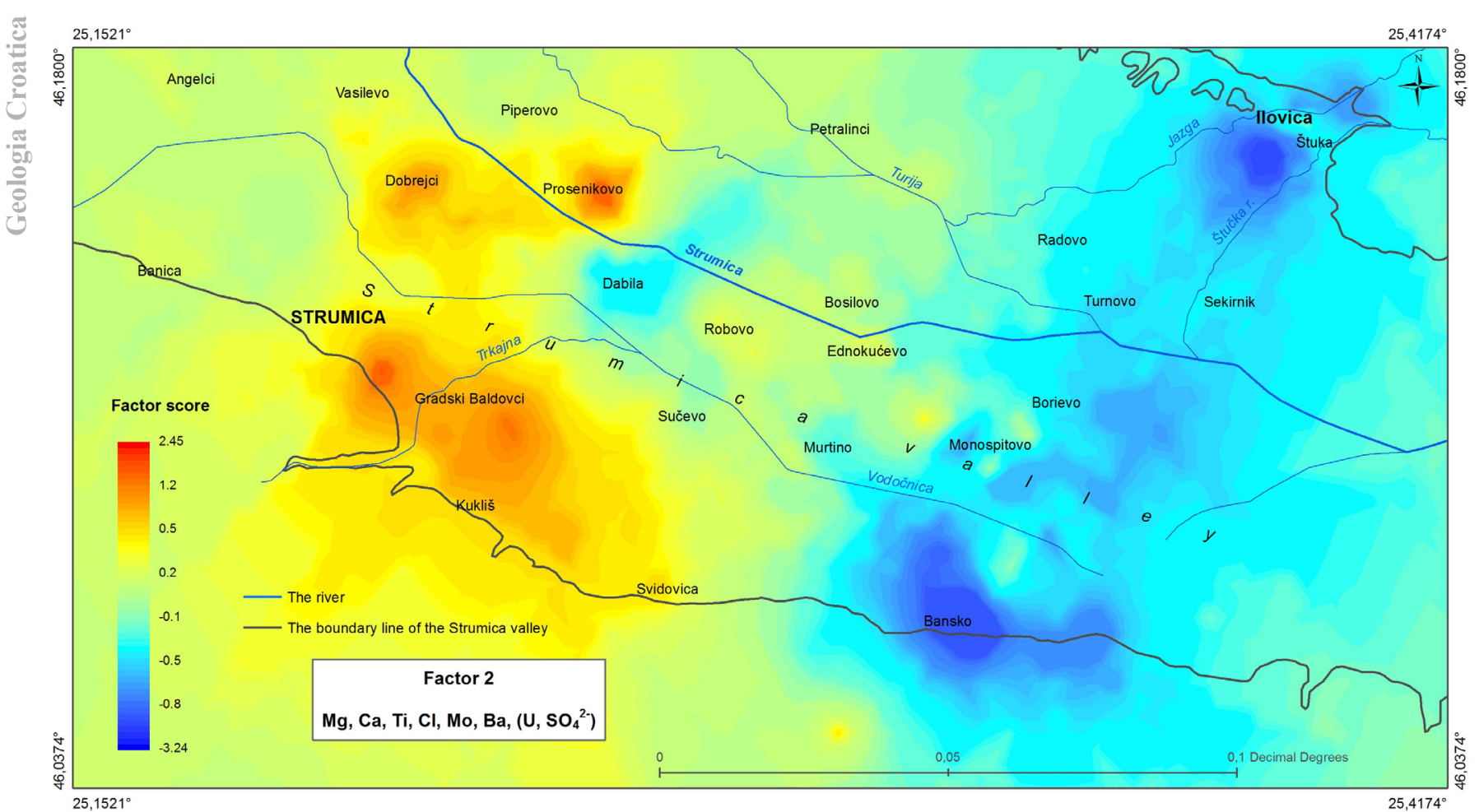

Figure 4. Spatial distribution of factor scores of Factor 2.

including uranium in the rhyolites of the Strumica region (RAKIKEVIK et al., 1978, 1980). The factor loadings of Ba and $\mathrm{SO}_{4}{ }^{2-}$ were almost the same; they are balanced as a result of the presence of sulphates which reduce the mobility of barium.

In the south-eastern part of the study area, factor scores were lower, with the lowest in the areas of Ilovica and Bansko.

The high factor scores of $\mathrm{Al}(0.79), \mathrm{Cu}(0.78), \mathrm{Pb}(0.67), \mathrm{Cr}$ $(0.51)$ and $\mathrm{Ni}(0.49)$ in factor 3 were recorded in the north-western and south-eastern parts of the investigated area, whereas in the middle zone, factor scores were lower (Fig. 5). The high factor score on a line from Piperovo - Prosenikovo - Strumica could be linked with some metal occurrences of copper, iron, chromium, uranium and magnetite in the Strumica region and farther north, especially in Kalugerica and Poderiš (RAKIKEVIK et al., 1978, 1980). The highest factor score of this factor was, as expected, in the Ilovica region, due to the mining of copper/gold (molybde-

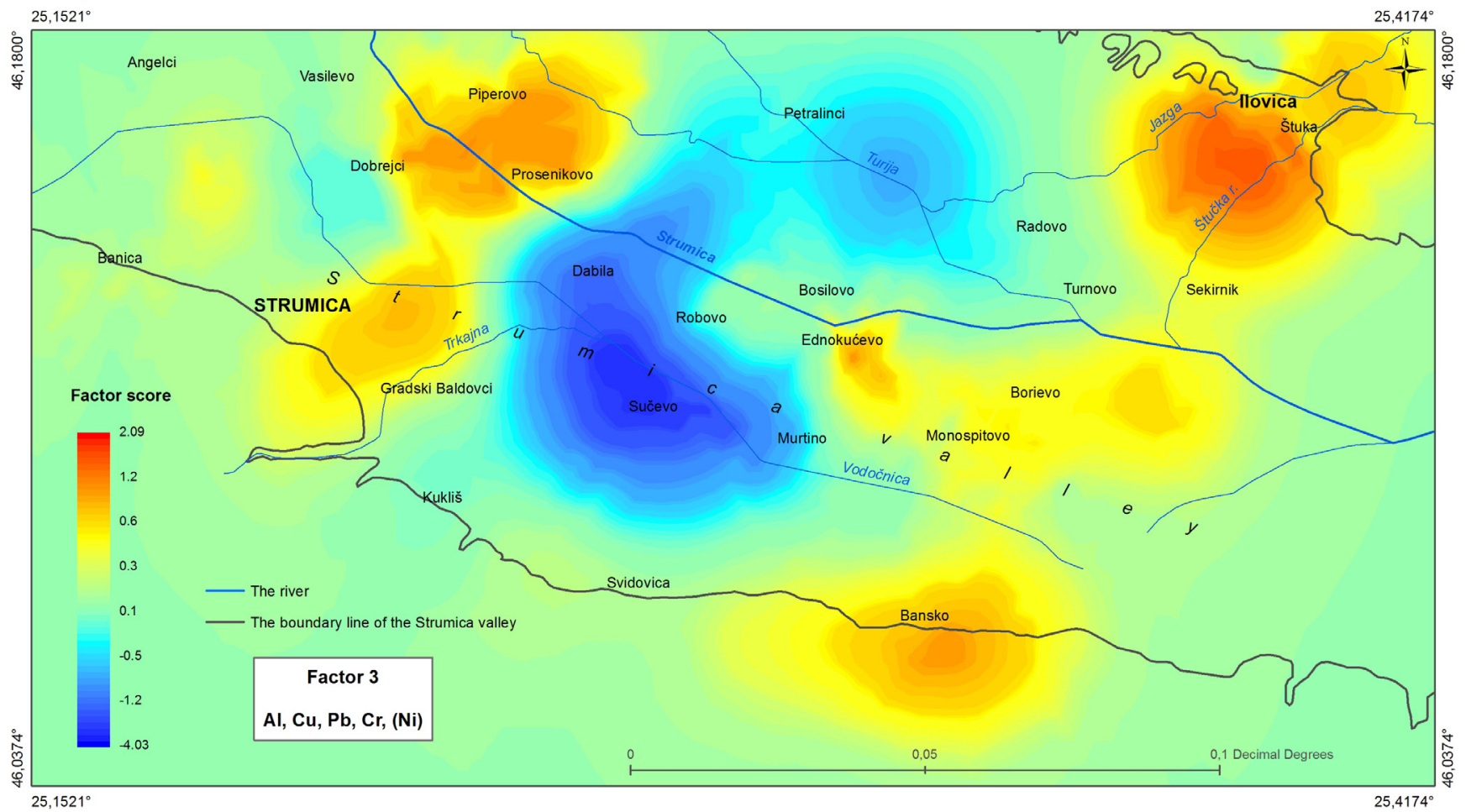

Figure 5. Spatial distribution of factor scores of Factor 3. 


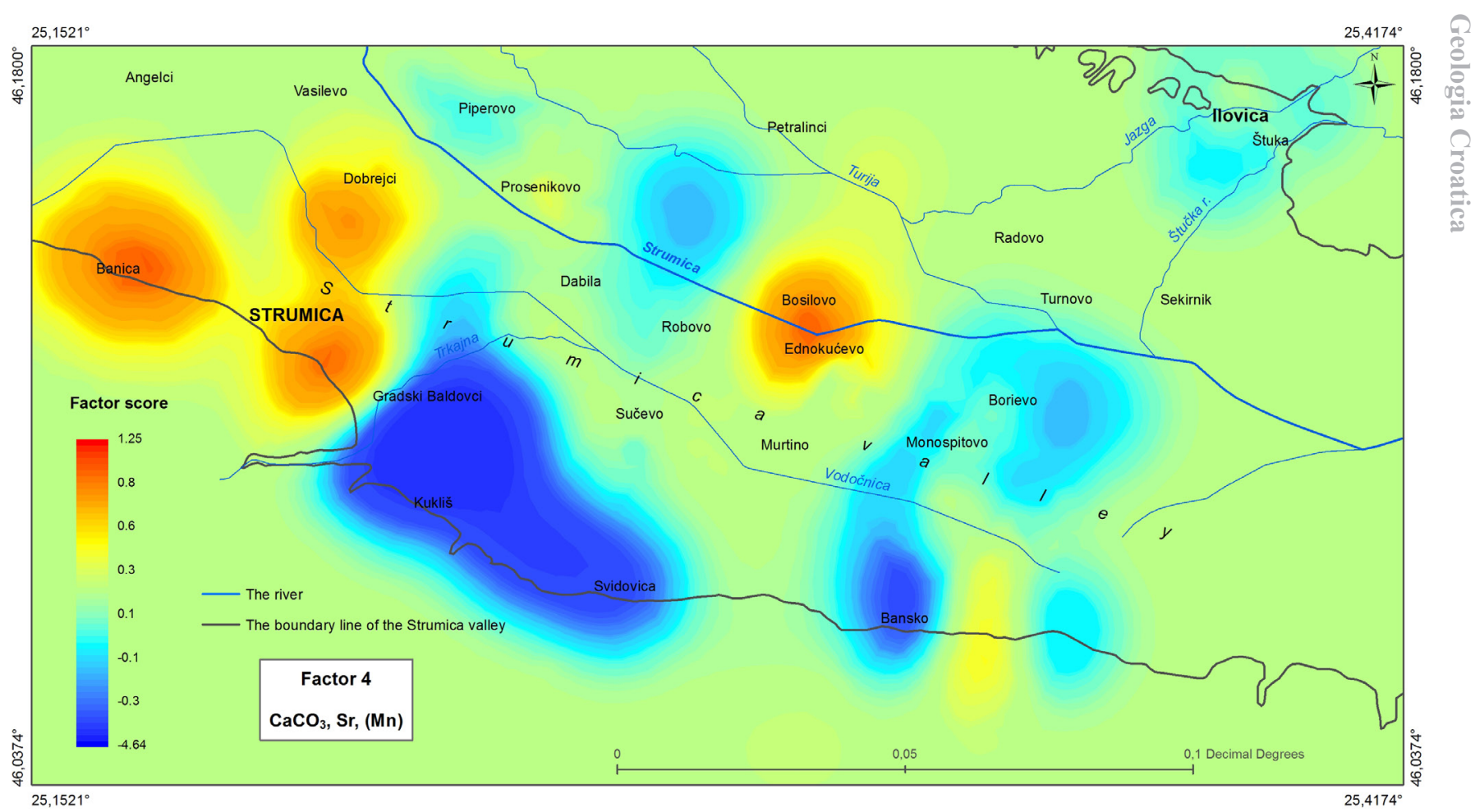

Figure 6. Spatial distribution of factor scores of Factor 4.

num) and numerous lead-zinc (copper) and gold occurrences. The Bansko area is well known as a geothermal reservoir and the geological background of the Ilovica and Bansko region is relevant to this (Fig. 2).

Factor 4 was characterized by high factor loadings of $\mathrm{CaCO}_{3}$ (0.94) and $\mathrm{Sr}(0.93)$ and low $\mathrm{Mn}(0.43)$ in the region of Banica, Strumica and Dobrejci (Fig 6). This part of the Vardar zone is defined by the presence of magmatites and metamorphites such as marble, which are good sources of $\mathrm{Ca}$ and $\mathrm{Sr}$ (RAKIKEVIK et al., 1978, 1980; Fig. 2). The lowest factor values were registered in the areas of Kukliš, Svidovica and Bansko.

The factor loadings of factors 5 were; $\mathrm{NO}_{3}^{-}(0.73), \mathrm{Ni}(0.56)$ and $\mathrm{Zn}(0.54)$. Higher factor scores were noted in the areas of Banica - Strumica, Ilovica, Bosilovo, Monospitovo and Svidovica (Fig. 7). Apart from the evident geological composition, factor loadings were increased by mining in Ilovica and agricul-

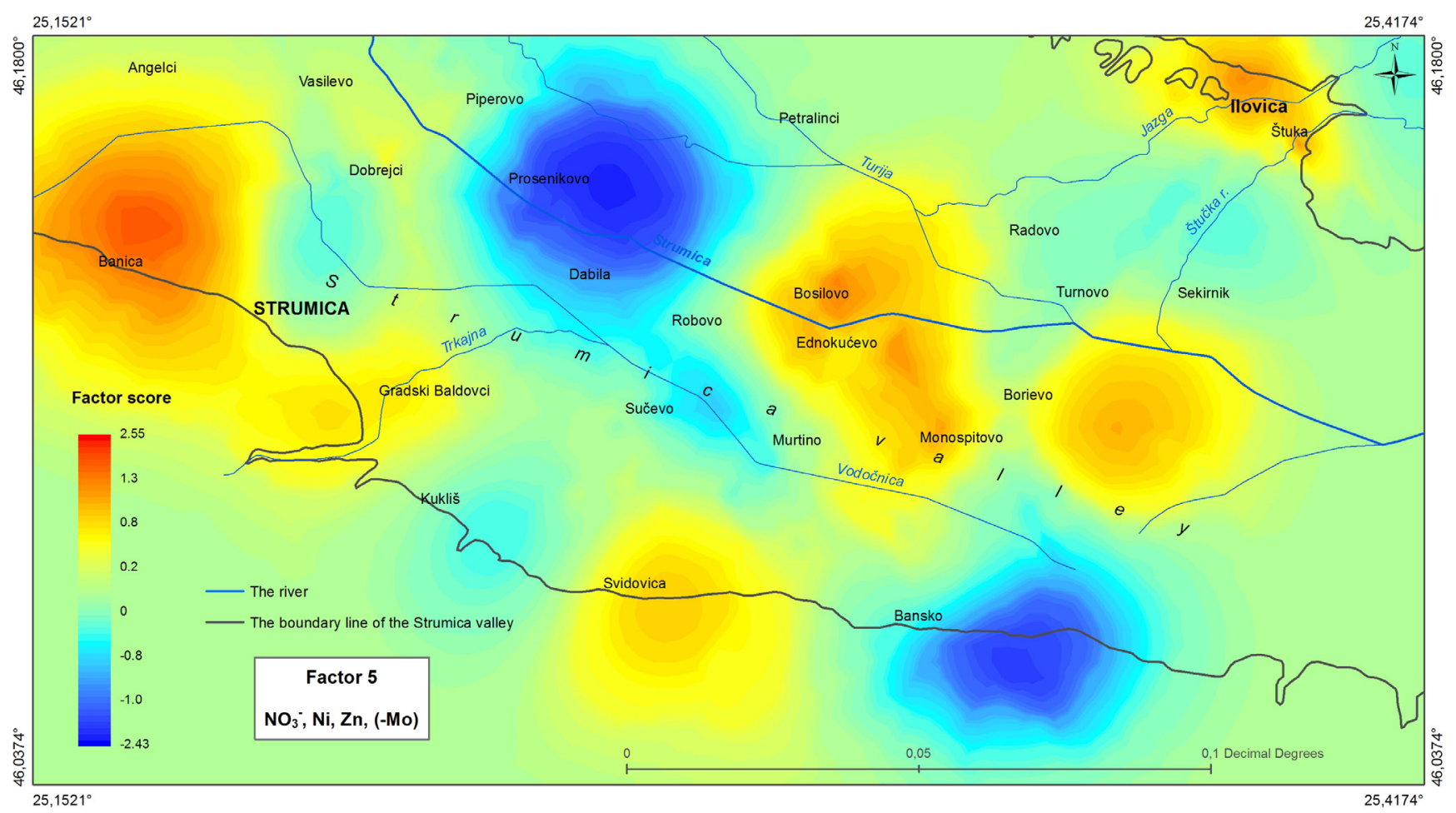

Figure 7. Spatial distribution of factor scores of Factor 5. 


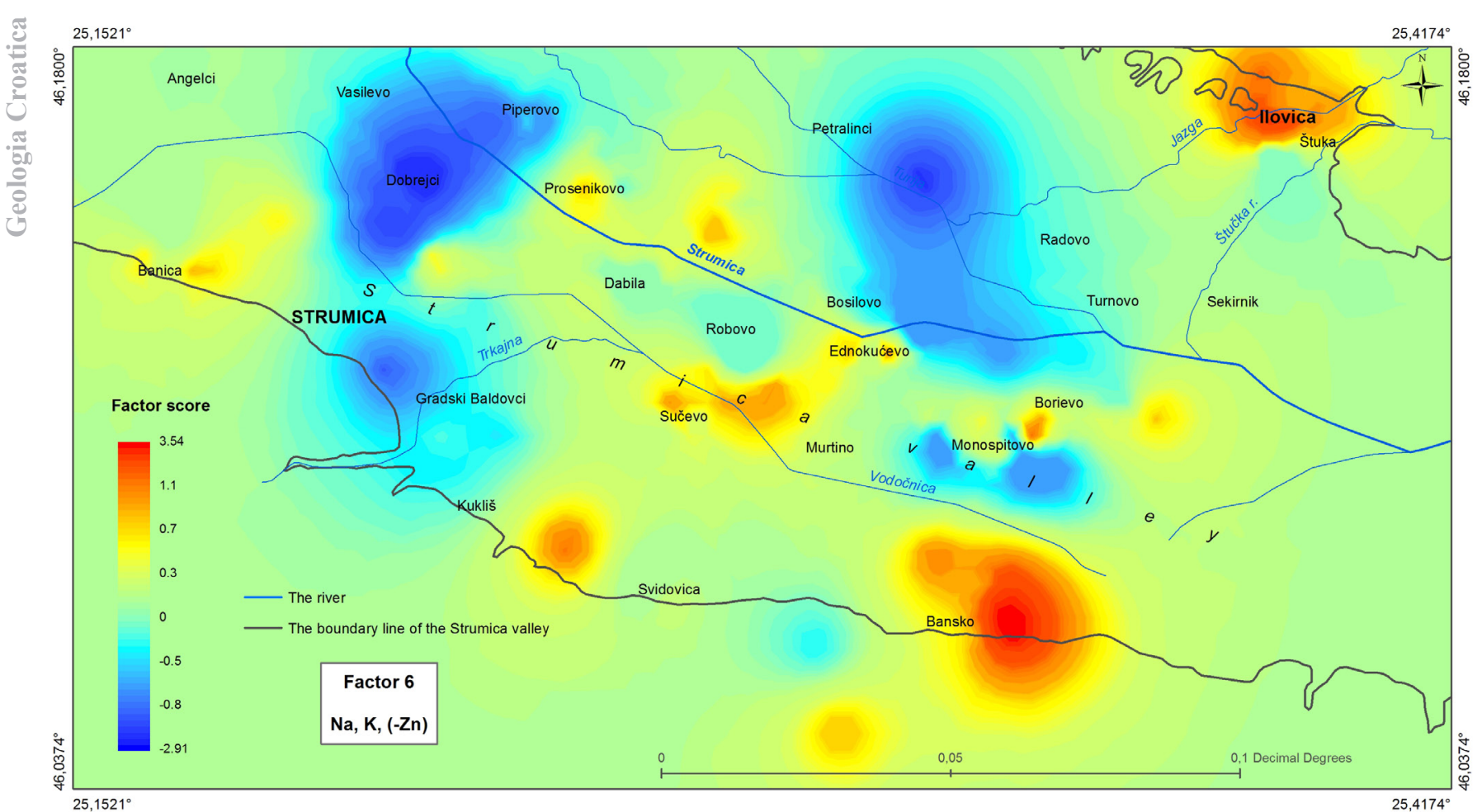

Figure 8. Spatial distribution of factor scores of Factor 6.

ture in other locations (RAKIKEVIK et al., 1978, 1980; Fig. 2; DISCOMAP, 2016).

A nitrate $\left(\mathrm{NO}_{3}{ }^{-}\right)$in factor 5 with a high factor value in the area of the Strumica and Banica settlements also probably stems from two types of origin, a natural one and another due to intensive agricultural production. A negative factor loading of Mo in factor 5 is a result of the geochemical behaviour of this metal. Weathered Mo tends to make strong complexes with organic mat- ter which reduce its mobility and entry into groundwater. Another reason is the opposite behaviour of Mo compared to most metals, as molybdenum is more mobile in the alkaline environment (SALMINEN et al., 2005).

The lowest factor scores were noted in two regions Prosenikovo - Debila and east of Bansko.

Figure 8. presents the distribution of factor scores of factor 6. Factor loadings are high for $\mathrm{Na}(0.76), \mathrm{K}(0.74)$ and $\mathrm{Zn}(-0.47)$.

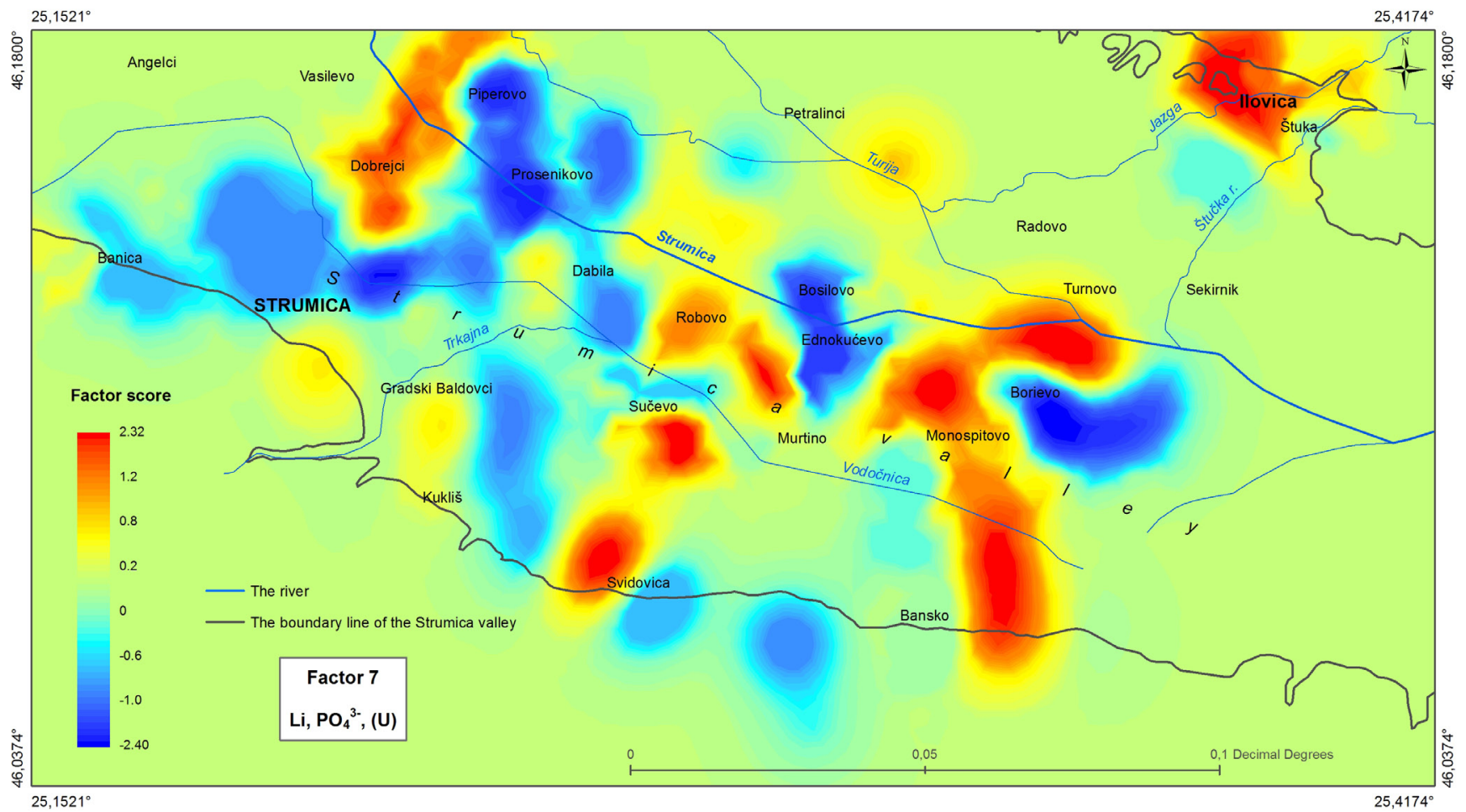

Figure 9. Spatial distribution of factor scores of Factor 7. 
The factor scores were highest in the zone east of Bansko and in the Ilovica areas. Zinc had a positive factor loading in factor 5 where it was correlated with $\mathrm{NO}_{3}{ }^{-}$and $\mathrm{Ni}$ and negative in factor 6 where it was correlated with $\mathrm{Na}$ and $\mathrm{K}$. The lowest factor scores were observed in the areas of Dobrejci, east of Petralinci and Bosilovo and south-east of the city of Strumica. The analytes were geogenic in origin.

The last factor with an eigenvalue $>1$ was factor 7 . The factor loadings in this factor were $\mathrm{Li}(0.81), \mathrm{PO}_{4}{ }^{3-}(0.57)$ and $\mathrm{U}(0.41)$ (Tab. 3; Fig. 9).

A possible explanation for the large variations in factor scores for this factor throughout the investigated is due to some local geological phenomena. In addition, phosphates $\left(\mathrm{PO}_{4}^{3-}\right)$ may be contributed due to the use of fertilizers and pesticides, septic systems and small amounts of manure.

The Ilovica region is home to porphyry copper/gold (molybdenum) ore which increased the concentration of metals in the groundwater (RAKIKEVIK et al., 1978, 1980; CARTER, 2007). Additionally, the high concentration of a number of the studied analytes was increased in groundwater due to intensive mining. This was one of the highest factor scores in the area of Ilovica in four factors $(3,5,6$, and 7$)$. The elevated factor loadings in the area were noted by a number of analytes: $\mathrm{Al}, \mathrm{Cu}, \mathrm{Pb}, \mathrm{Cr}, \mathrm{NO}^{3-}$, $\mathrm{Ni}, \mathrm{Zn}, \mathrm{Na}, \mathrm{K}, \mathrm{Li}$ and $\mathrm{PO}_{4}{ }^{3-}$.

\section{CONCLUSION}

Performing factor analysis yielded 7 factors with eigenvalues $>1$ which explained $70.0 \%$ of the variance in the data. Factors 1,2 , 3, 4, 5, 6 and 7 explained 13.9, 13.7, 11.2, 9.6, 8.0, 7.5 and $6.2 \%$ of variance, respectively. The chemistry of groundwater in Strumica valley was predominantly influenced by the geology, and only some minor additional anthropogenic effects were recorded.

The clear regional geological background was observed in factors 1, 2, 3 and partly in factors 4 and 5. The last two factors 6 and 7 were affected by more local geological variations. The high factor loading of As in factor 1 could be linked to the elevated concentration of arsenic in groundwater. The observed increase of As was predominantly attributed to the geogenic background and to a lesser degree due to anthropogenic influences, especially intensive agricultural production. Further research is required on this subject.

Besides arsenic, some nitrate, phosphates and some metals, including $\mathrm{Cu}, \mathrm{Pb}, \mathrm{Cr}, \mathrm{Ni}, \mathrm{Zn}$, Li have an anthropogenic origin as a consequence of intensive agriculture production and/or mining. The influence of mining in Ilovica on the groundwater in the Strumica valley was of a more local nature.

\section{REFERENCES}

CARTER, G.S. (2007): Technical report on the copper gold resources on the Ilovitza Project, Macedonia on behalf of Euromax Resources Limited.- Report for NI 43101, Broad Oak Associates, Toronto, Ontario, Canada.

DALMACIJA, B. \& AGBABA, J. (eds.) (2006): Kontrola kvaliteta vode za piće [Quality control of drinking water - in Serbian].- Prirodno-matematički fakultet, Departmant za hemiju, Novi Sad.

DISCOMAP (2016): http://discomap.eea.europa.eu/map/EEABasicviewer/?webmap=b 5 cbf63906584ef2ac5d29d627faf923 (22.2.2016).
EPA (Environmental Protection Agency) Method 305.1 (1974a): Acidity by Titration.Approved for NPDES. Editorial revision 1974.

EPA (Environmental Protection Agency) Method 350.2 (1974b): Nitrogen, Ammonia (Colorimetric, titrimetric, potentiometric distillation procedure).- Approved for NPDES. Editorial revision 1974.

EPA(Environmental Protection Agency) Method 375.4 (1978): Sulfate (Turbidimetric).Approved for NPDES. Editorial revision 1978.

ILIĆ POPOV, S., STAFILOV, T., ŠAJN, R., TĂNĂSELIA, C. \& BAČEVA, K. (2014): Applying of Factor Analyses for Determination of Trace Elements Distribution in Water from River Vardar and Its Tributaries, Macedonia/Greece.- Hindawi Publishing Corporation, The Scientific World Journal, 2014, 11 p. doi:10.1155/2014/809253

IVKOVIĆ, A., ŠARIN, A. \& KOMATINA, M. (1983): Tumač za hidrogeološku kartu SFR Jugoslavije 1:500000 [Eplanation for hydrogeological map of SFR Yugoslavia, 1:500000 - in Croatian].- Savezni geološki zavod, Beograd.

JOHNSTON, D. (2007): EPA Guidelines: Regulatory monitoring and testing Groundwater sampling.- Environmental Protection Agency, 38 p. ISBN 978-1-92112548-5.

JOVANOVSKI, M. (2009): Hydrogeological Survey on Groundwater in Macedonia.GTZ Project, Skopje. https://www.researchgate.net/publication/282612958_Hydrogeological_survey_of_Groundwater_in_Macedonia?enrichId=rgreq6d809b4d-970d-4e89-928d-324c897e3ba7\&enrichSource=Y292ZXJQYWdlOzI 4MjYxMjk1ODtBUzoyODE2Mzg5NTgzMjE2Nj1AMTQ0NDE1OTM2ODQ4 $\mathrm{Mg} \% 3 \mathrm{D} \% 3 \mathrm{D} \& \mathrm{el}=1 \_\mathrm{x} \_2(16.2 .2016)$

KABATA-PENDIAS, A. \& MUKHERJEE, A.B. (2007): Trace elements from soil to human.- Springer-Verlag Berlin Heidelberg, $561 \mathrm{p}$.

KABATA-PENDIAS, A. \& PENDIAS, H. (2001): Trace elements in soils and plants.3rd ed., CRC Press, Boca Raton, FL. 403 p.

KAISER, H.F. (1960): The application of electronic computers to factor analysis.- Educational and Psychological Measurement, 20, 141-151.

MAKSOIL (2016): http://www.maksoil.ukim.mk/masis/ (22.2.2016).

MICEVSKI, E., POPOVSKI, K. \& LIGOVSKI, M. (2005): Hydrogeothermal Potential of the Strumica Valley with a Special Review of the Bansko Locality.- Proceedings World Geothermal Congress, Antalya, Turkey, 24-29 April 2005.

MIRČOVSKI, V., BOEV, B., EFREMOSKI, Z., ŠORŠA, A. \& DIMOV., Đ. (2015): Hydrochemical data for the ground waters in the Bitola's part of the Pelagonia valley, Republic of Macedonia.- Geologica Macedonica, 29, 1, 15-24.

OFFICIAL GAZETTE OF REPUBLIC OF MACEDONIA (1998): Law on waters.Skopje, No. 4/98.

OFFICIAL GAZETTE OF REPUBLIC OF MACEDONIA(1999): Regulation for Classification of Water-- Skopje, No. 18/99.

POPOVSKA, C. \& GESHOVSKA, V. (2014): Water Balance Model for Vulnerability Assessment of Water Resources in Strumica River Basin.- Irrigation \& Drainage Systems Engineering, 3, p. 127. doi:10.4172/2168-9768.1000127.

RAKIKEVIK, T., PENDŽEROVSKI, J. \& KOVAČEVIK, M. (1978): Osnovna geološka karta SFRJ 1:100000, list Strumica K34-94 [Basic Geological Map of SFRY 1:100000, Strumica sheet - in Macedonian].-Geološki zavod, Skopje (1969-1972), Savezni geološki zavod, Beograd.

RAKIKEVIK, T., KOVAČEVIK, M., RADOVIK, N. \& PENDŽEROVSKI, J. (1980): Osnovna geološka karta SFRJ 1:100000. Tumač za list Strumica K34-94 [Basic Geological Map of SFRY 1:100000, Geology of the Strumica sheet - in Macedonian].- Geološki zavod, Skopje, Savezni geološki zavod, Beograd, 69 p.

REIMANN, C. \& FILZMOSER, P. (2000): Normal and lognormal data distribution in geochemistry: death of a myth. Consequences for the statistical treatment of geochemical and environmental data.- Environmental Geology, 39, 1001-1014.

REIMANN, C., FILZMOSER, P., GARRETT, R.G. \& DUTTER, R. (2008): Statistical Data Analysis Explained.- John Wiley \& Sons, Ltd., 362 p.

ROLLINSON, H. (1993): Using Geochemical Data: Evaluation, Presentation, Interpretation.- Longman Group UK Limited, England, 352 p.

SALMINEN, R., BATISTA, M.J., BIDOVEC, M., DEMETRIADES, A., DE VIVO, B., DE VOS, W., DURIS, M., GILUCIS, A., GREGORAUSKIENE, V., HALAMIĆ, J., HEITZMANN, P., JORDAN, G., KLAVER, G., KLEIN, P., LIS, J., LOCUTURA, J., MARSINA, K., MAZREKU, A., O'CONNOR, P.J., OLSSON, S.Å., OTTESEN, R.-T., PETERSELL, V., PLANT, J.A., REEDER, S., SALPETEUR, I., SANDSTRÖM, H., SIEWERS, U., STEENFELT, A. \& TARVAINEN, T. (2005): Geochemical Atlas of Europe, Part 1, Background Information, Methodology and Maps.- Geological Survey of Finland, Espoo, 526 p.

ŠIJAKOVA-IVANOVA, T. \& AMBARKOVA, V. (2015): Geochemical assessment of some natural waters from eastern and south-eastern Macedonia.- Geologia Macedonica, 29, 1, 5-14. 